\title{
Genotypic Variation in Pharmacological Potential of Seed Extracts of Cumin (Cuminum cyminum L.) Genotypes
}

\author{
DOLLY AGARWAL, S. N. SAXENA*, P. N. DUBEY, B. K. MISHRA, K. KANT AND G. LAL \\ ICAR-National Research Centre on Seed Spices, Tabiji, Ajmer-305 206, India
}

Agarwal et al.: Pharmacological potential of Cuminum cyminum seed extracts

\begin{abstract}
Earlier work was mostly focused on the therapeutic properties of Cuminum cyminum seeds commonly known as cumin obtained from local market with no genetic purity. Present study was conducted for evaluating therapeutic potential of cumin seeds in relation to their genetic variability. Methanol and hexane seed extracts of cumin genotypes GC-1, GC-4, RZ-19, RZ-209 and RZ-341 were tested on albino mice for evaluating therapeutic properties. Both seed extracts were found to possess antimicrobial, antiinflammatory, antidiabetic, hypolipidemic and antihypertensive properties, which varied significantly among the 5 genotypes. Hexane seed extract of cumin genotype RZ-209 and RZ-341 possessed enhanced antibacterial properties while methanol extract of RZ-341 was highly effective as a hypolipidemic. Genotypes GC-1 and GC-4 exhibited greater antihypertensive and antifungal activity, respectively. Antiinflammatary activity was higher in methanol extract of genotype GC-1 whereas antidiabetic activity was high in hexane extract of genotype GC-1. This study provided experimental evidence for the use of cumin extracts for treating various ailments as well as provided basis to identify suitable genotypes of this important spice for a particular therapy.
\end{abstract}

Key words: Cuminum cyminum, genetic variability, pharmacological properties, seed extract, seed spices

Cumin (Cuminum cyminum L.) is an important seed spice crop grown in arid and semi-arid climatic conditions that prevails in Asian countries like India, China, Iran and Indonesia. This crop has long association with Homo sapiens in term of its cultivation and use similar to coriander, which was well known to the Romans that used the seeds as an alternative to pepper and used in ground state as paste for spreading on bread and meat. Among various seed spice crops cultivated in India, cumin crop covers 760130 ha area with a production of 485480 tones. The main cumin growing belt in India includes the states of Rajasthan and Gujarat. Cumin seeds have characteristic strong aroma, which gets easily modified on frying or dry toasting. Ripe seeds of cumin bounded with $\sim 3-4 \%$ essential oil being used in confectionary and perfumery industries. Cumin and its value added products are used in food flavouring and perfumery. Most abundant constituent of cumin essential oil is cuminaldehyde (45-50\%) and terpenes, which account for many health benefits ${ }^{[1,2]}$. Cumin seeds in various forms have been used in folk and traditional medical practices known as Ayurveda

*Address for correspondence E-mail: shail.nrcss@gmail.com

September-October 2019 in India and Indian sub-continent. The practiced uses of cumin for various ailments have been reported by several authors ${ }^{[2-4]}$. Many researchers analysed cumin and related species for the presence of medicinally important compounds being used for their antioxidative potential ${ }^{[5-9]}$, antimicrobial activity ${ }^{[10-13]}$, antidiabetic $\operatorname{activity}^{[14-16]}$ and hypolipidemic activity ${ }^{[16-18]}$. These medicinal properties are most likely due to the presence of bioactive constituents, which are basically the secondary metabolites ${ }^{[19]}$.

Studies conducted to validate the health benefit properties of cumin seeds have been compiled in many reviews ${ }^{[2,4]}$. Cumin seeds have been analysed for nutraceutical functions and recommended to enhance dietary proportion of cumin in other than traditional

This is an open access article distributed under the terms of the Creative Commons Attribution-NonCommercial-ShareAlike 3.0 License, which allows others to remix, tweak, and build upon the work non-commercially, as long as the author is credited and the new creations are licensed under the identical terms

Accepted 25 August 2019

Revised 31 May 2019

Received 21 Janaury 2019

Indian J Pharm Sci 2019;81(5):946-954 
uses $^{[20]}$. In a recent study ${ }^{[21]}$ cumin seeds collected from major cumin producing areas in India have been evaluated for oil content and constituents as well as presence of phenolics, flavonoids, mineral composition, unsaturated fatty acids and antioxidant capacity. This study suggested significant environmental effect on seed chemical profile, which instigated research to evaluate the medicinal potential of different cumin genotypes from the two different geographical locations in India to identify cumin genotypes with desirable seed quality specifically suitable for medicinal or industrial purposes. In an earlier report the authors evaluated aqueous, methanol, hexane and dimethyl sulfoxide (DMSO) seed extracts of 5 cumin genotypes for presence of phenolics, flavonoid and antioxidative properties and found significant genotypic variation $^{[22]}$. Maximum phenolic content was observed in methanol seed extract of all cumin genotypes with an average value of $85.64 \mathrm{mg} \mathrm{GAE} / \mathrm{g}$ while minimum total phenolic content was observed in genotype RZ 19 (70.464 mg gallic acid equivalent, GAE/g). Total flavonoid content was ranging from a minimum of 38.05 in RZ 19 to a maximum of $55.07 \mathrm{mg}$ quercetin equivalent, QE/g in RZ 341. Antioxidant content was found maximum (36.93 mg butylated hydroxytoluene equivalent, BHTE/g) in DMSO seed extract of RZ 209, while minimum (10.588 mg BHTE/g) was observed in methanol extract of RZ $19^{[22]}$. In continuance, present study was conducted on the antimicrobial, antiinflammatory, antidiabetic, hypolipidemic and antihypertensive properties of extracts of these 5 cumin genotype seeds.

\section{MATERIALS AND METHODS}

Methanol, hexane, nutrient agar, yeast extract potato dextrose agar (YEPD), potato dextrose agar (PDA) medium, Sabouraud dextrose, Mueller-Hinton agar (MHA), cefixime, griseofulvin and captopril were procured from Sigma-Aldrich (St. Louis, MO, USA).

\section{Plant materials:}

ICAR-National Research Centre on Seed Spices maintaining active germplasm centre for seed spices. Pure seeds of cumin genotypes (GC-1, GC-4, RZ-19, RZ-209 and RZ-341) were obtained from seed store of ICAR-NRCSS, Ajmer and used for preparation of methanol and hexane seed extracts for this investigation.

\section{Preparation of seed extracts:}

Ground cumin seed powder ( $1 \mathrm{~g}$ ) of each genotype was extracted with $5 \mathrm{ml}$ of methanol and hexane separately. After filtration the residue powder was again soaked in respective solvent for $24 \mathrm{~h}$. Obtained extracts were mixed together and made to $10 \mathrm{ml}$ by adding the respective solvents. Dry crude seed extract was obtained by evaporating the solvent in a rotary flash evaporator (JSGW, Ambala, India) and used as crude drug for evaluation of medicinal activities.

\section{Antimicrobial activity:}

Four bacterial and 2 fungal strains were used to assay the antimicrobial potency of cumin seed extracts. Bacterial strains used were, Staphylococcus aureus, Streptococcus pyogenes were Gram-positive while, Escherichia coli, Pseudomonas aeruginosa were Gram-negative and fungal strains used were Candida albicans and Aspergillus clavatus. The bacterial strains were cultured on nutrient agar/YEPD using spread plate technique whereas, fungal stock cultures were inoculated on PDA medium and incubated for $24 \mathrm{~h}$ at $37^{\circ}$. The bacterial strains were grown in MHA plates at $37^{\circ}$ (the bacteria were grown in the nutrient broth at $37^{\circ}$ ), whereas the $C$. albicans and A. clavatus were grown in Sabouraud dextrose agar and PDA media, respectively, at $28^{\circ}$. The pure stock cultures of bacteria and fungi were maintained at $4^{\circ}$.

\section{Determination of zone of inhibition:}

In vitro antimicrobial properties of cumin seed extracts were assessed as per Mueller-Hinton test ${ }^{[23]}$. Sample concentration was kept $25 \mu \mathrm{g} / \mathrm{ml}$, while that of standard drugs at 5, 25 and $50 \mu \mathrm{g} / \mathrm{ml}$. MuellerHinton sterile agar plates were inoculated with the 4 bacterial strains and 2 fungal strains $\left(10^{8} \mathrm{cfu}\right)$ and incubated at $37^{\circ}$ for $3 \mathrm{~h}$. Cefixime and griseofulvin was used as standard antibiotic and fungicide, respectively. Growth inhibition zone was measured after 24 and $48 \mathrm{~h}$, respectively for bacteria and fungi. Inhibition zone $<8 \mathrm{~mm}$ was considered ineffective.

\section{Acute oral toxicity/toxic class method:}

The acute oral toxicity was carried out as per the guidelines set by Organization for Economic cooperation and Development (OECD), revised draft guidelines 423, received from Committee for the Purpose of Control and Supervision of Experiments on Animals (CPCSEA), Ministry of Social Justice and Empowerment, Government of India. The principle is based on a stepwise procedure with the use of a minimum number of animals per step to obtain 
sufficient information on the acute toxicity of the test substance to enable its classification.

\section{Antiinflammatory properties:}

Starved Wistar rats (150 to $200 \mathrm{~g}$ ) were given $5 \mathrm{ml}$ of water and seed extract uniformly. A subcutaneous injection of $1 \%$ carrageenan was given on right hind paw and marked at the level of the lateral alveolus and immersed in mercury up to this mark. Before immersion paw volume was measured by using plethysmograph after 1-4 $\mathrm{h}$ after carrageenan injection. Rats were divided into 13 groups of 6 rats each according to the treatment administered. Group I rats only vehicle, group II- carrageenan $(0.1 \mathrm{ml}$ of $1 \% \mathrm{mg} / \mathrm{kg}$, po), group IIIcarrageenan $(0.1 \mathrm{ml}$ of $1 \% \mathrm{mg} / \mathrm{kg}$, po $)+$ diclofenac $(12.5 \mathrm{mg} / \mathrm{kg}$, po), group IV-XIII- carrageenan $(0.1 \mathrm{ml}$ of $1 \% \mathrm{mg} / \mathrm{kg}$, po)+methanol or hexane extract of cumin seeds (400 mg/kg, po).

\section{Hypolipidemic activity:}

Effect of cumin seed extracts on lipid profile parameters were evaluated on Wistar rats divided into 19 groups. A group of rats were given high cholesterol diet for $15 \mathrm{~d}$ while another group was given this diet along with simvastatin $(100 \mathrm{mg} / \mathrm{kg}$, po). Rats of group IVXIX were given high cholesterol diet along with seed extracts of different cumin genotypes ( $400 \mathrm{mg} / \mathrm{kg}$, po). Control group rats (group I) were given only vehicle. Lipid profile that included total cholesterol, triglycerides, low-density lipoprotein (LDL) and highdensity lipoprotein (HDL) were determined on d 16 of treatment and compared with control.

\section{Antidiabetic activity:}

Seed extracts (400 mg/kg, po) and gilbenclamide were fed orally to experimental rats 30 min prior to loading glucose $(2 \mathrm{~g} / \mathrm{kg})$. Control group of rats were given only water. Samples were collected from the tail vein after 30, 60, 120 and 240 min of glucose loading and level of glucose in treated as well as fasting was measured with standard glucometer.

\section{Antihypertensive properties:}

Antihypertensive properties of genotype GC-1 was evaluated by administering methanol and hexane seed extracts (250 to $300 \mathrm{~g} / \mathrm{kg}$ ) to spontaneously hypertensive rats and Wistar rats. Prior to dividing the rats in to groups, they were kept under controlled environmental conditions with ration and water as and when required for acclimatization. Wistar rats were used as normotensive control, given same volume of water $(0.1 \mathrm{ml} / 100 \mathrm{~g})$ and divided into 4 groups of 6 rats each. Urethane $20 \%(0.8 \mathrm{~g} / \mathrm{kg}$, ip $)$ and pentobarbital sodium $1 \%(40 \mathrm{mg} / \mathrm{kg}$, ip) was used to anesthetize the rats. To facilitate drug and seed extract administration tracheostomy was created by cannulising right femoral vein followed by bolus injection of heparin (30 IU). The left carotid artery was cannulated for mean arterial pressure recording using a pressure transducer (Mod F-60, Narco Biosystems, Inc., Houston, Texas, USA) connected with a Narcotrace 40 polygraph (Narco Biosystems, Inc., Texas, USA). The hemodynamic variables were allowed to stabilize for 15 min before administration of test substances prepared in saline. Acetyl choline (ACh, $1.0 \mu \mathrm{g} / \mathrm{kg}$, iv) was chosen as standard drug. Group I-rats were given only vehicle while group II was given captopril $40 \mathrm{mg} / \mathrm{kg}$, ip and group III-IV were given cumin seed extracts (200 mg/kg, ip).

\section{Statistical analysis:}

All results were obtained in triplicate and were expressed as mean. The data were analysed in statistical software SAS 9.3. The statistical significance of the differences among means was determined using analysis of variance ${ }^{[24]}$. $\mathrm{P}<0.05$ indicated statistical significance.

\section{RESULTS AND DISCUSSION}

Zone of inhibition and \% inhibition produced by methanol and hexane seed extracts of cumin genotypes and cefixime are presented in Table 1. Both the solvent extracts displayed variable antibacterial activity on both Gram-positive and -negative bacterial strains. In Gram-positive bacterial group, methanol seed extract of cumin genotype RZ-209 showed minimum (50\%) inhibition, while maximum (73\%) inhibition was exhibited by the genotype GC-1 and RZ-341. In Gram-negative bacterial group this ranged from a minimum (58\%) produced by genotype RZ-341 to a maximum (76\%) by GC-1 and RZ-209. When methanol seed extract was substituted with hexane seed extract, minimum inhibition (58\%) in S. aureus was recorded with GC-1 and RZ-341 whereas it was $62 \%$ with GC-4 and RZ-209. Maximum (66\%) inhibition was recorded with RZ-19. Seed extracts were found more effective against another bacteria, $S$. pyogenes, which showed minimum inhibition in GC-1 (62\%) and maximum in RZ-209 (76 \%) followed by RZ-341 (73 \%) GC-4 (69\%) and RZ-19 (66\%, Table 1). 
On the two Gram-negative bacteria, GC-1 and RZ-209 methanol extracts were slightly more effective against $E$. coli with a maximum inhibition $(76 \%)$, while the methanol extract of RZ-19 was less effective (66\%) and on $P$. aeruginosa it produced $58 \%$ inhibition. GC-1 methanol extract produced a maximum inhibition of $69 \%$ inhibition of $P$. aeruginosa. However, hexane seed extract of genotype RZ-209 was more effective against $P$. aeruginosa with highest zone of inhibition $(24 \mathrm{~mm})$ followed by GC-4 $(22 \mathrm{~mm}), \mathrm{GC}-1(21 \mathrm{~mm})$ and RZ-341 (20 mm).

Methanol and hexane seed extracts were tested against $C$. albicans and A. clavatus in comparison with griseofulvin $(25 \mu \mathrm{g} / \mathrm{ml})$. As compared to standard fungicide maximum (61\%) inhibition was recorded with methanol seed extract of GC-4. Methanol seed extract of genotype RZ-209 was least effective as it produced $18 \mathrm{~mm}$ zone of inhibition while hexane seed extract of genotype RZ-19 produced a maximum of $23 \mathrm{~mm}$ zone of inhibition on C. albicans and A. clavatus whereas minimum zone $(18 \mathrm{~mm})$ was observed in genotype GC-4. Hexane seed extract was more effective against $A$. clavatus as compared to methanol extract where seed extract of RZ-209 produced $15 \mathrm{~mm}$ zone of inhibition (Table 2).

Cumin along with other spices is traditionally used for enhancing taste and flavour viz-a-viz to add preservation of stored food, pickles in Asian cuisines. Apart from other medicinal benefits cumin seeds showed strong antimicrobial activities ${ }^{[25-34]}$. Results of present investigation are in agreement with earlier reports. Methanol seed extract of cumin was found effective against 4 enteropathogenic and food spoiler bacterial strains ${ }^{[11]}$. Antifungal properties of cumin essential oil were evaluated using agar disc diffusion assay $^{[11,14]}$ and the results indicated that cumin oil possessed antifungal property as it inhibited mycelia growth of all fungal species tested. Supplementation of standard antifungals with cumin oil resulted in reduced MIC of the antifungals suggested synergistic action of cumin oil. In the present investigation crude seed extract was used instead of pure essential oil and found significant antifungal properties suggesting the use of cumin seed extract along with antifungal drug, which might be helpful in reducing toxicity induced by antifungal drug alone viz-a-viz increasing effectiveness of treatment.

Paw oedema volume of treated rats as a measure of inflammation and effect of seed extracts of cumin was presented in Table 3. Control group rats showed a paw oedema of $3.4 \mathrm{ml}$ during 0 to $4 \mathrm{~h}$. Drug-induced inflammation was ranged from 3.3 to $6.8 \mathrm{ml}$ during observation period. Standard diclofenac at $12.5 \mathrm{mg} / \mathrm{kg}$ was able to reduce inflammation and bring this down

TABLE 1: ANTIBACTERIAL ACTIVITY OF CUMIN SEED EXTRACT OF DIFFERENT GENOTYPES

\begin{tabular}{|c|c|c|c|c|c|c|c|c|c|}
\hline \multirow[b]{3}{*}{ Genotypes } & \multirow{3}{*}{$\begin{array}{c}\text { Concentration } \\
(\mu g / m l)\end{array}$} & \multicolumn{8}{|c|}{ Zone of inhibition (mm) } \\
\hline & & \multicolumn{2}{|c|}{ S. aureus } & \multicolumn{2}{|c|}{ S. pyogenes } & \multicolumn{2}{|c|}{ E. coli } & \multicolumn{2}{|c|}{ P. aeruginosa } \\
\hline & & $\begin{array}{l}\text { Methanol } \\
\text { seed } \\
\text { extract }\end{array}$ & $\begin{array}{c}\text { Hexane } \\
\text { seed } \\
\text { extract }\end{array}$ & $\begin{array}{l}\text { Methanol } \\
\text { seed } \\
\text { extract }\end{array}$ & $\begin{array}{c}\text { Hexane } \\
\text { seed } \\
\text { extract }\end{array}$ & $\begin{array}{c}\text { Methanol } \\
\text { seed } \\
\text { extract }\end{array}$ & $\begin{array}{l}\text { Hexane } \\
\text { seed } \\
\text { extract }\end{array}$ & $\begin{array}{c}\text { Methanol } \\
\text { seed } \\
\text { extract }\end{array}$ & $\begin{array}{c}\text { Hexane } \\
\text { seed } \\
\text { extract }\end{array}$ \\
\hline Cefixime & 25 & \multicolumn{2}{|c|}{$32(100)$} & \multicolumn{2}{|c|}{$35(100)$} & \multicolumn{2}{|c|}{$37(100)$} & \multicolumn{2}{|c|}{$37(100)$} \\
\hline GC-1 & 25 & $20(73)$ & $16(58)$ & $19(69)$ & $17(62)$ & $21(76)$ & $18(66)$ & $19(69)$ & $21(76)$ \\
\hline GC-4 & 25 & $19(69)$ & $17(62)$ & $18(66)$ & $19(69)$ & $19(69)$ & $16(58)$ & $18(66)$ & $22(80)$ \\
\hline RZ-19 & 25 & $17(62)$ & $18(66)$ & $18(66)$ & $18(66)$ & $18(66)$ & $19(69)$ & $18(66)$ & $21(76)$ \\
\hline RZ-209 & 25 & $13(50)$ & $17(62)$ & $19(69)$ & $21(76)$ & $21(76)$ & $17(62)$ & $17(62)$ & $24(87)$ \\
\hline $\mathrm{RZ}-341$ & 25 & $18(66)$ & $16(58)$ & $20(73)$ & $20(73)$ & $19(69)$ & $15(54)$ & $16(58)$ & $20(73)$ \\
\hline
\end{tabular}

Value in parenthesis is percent inhibition of zone

TABLE 2: ANTIFUNGAL ACTIVITY OF METHANOL AND HEXANE EXTRACT OF CUMIN

\begin{tabular}{|c|c|c|c|c|c|}
\hline \multirow{3}{*}{ Genotypes } & \multirow{3}{*}{$\begin{array}{c}\text { Concentration } \\
(\mu \mathrm{g} / \mathrm{ml})\end{array}$} & \multicolumn{4}{|c|}{ Zone of inhibition $(\mathrm{mm})$} \\
\hline & & \multicolumn{2}{|c|}{ Candida albicans } & \multicolumn{2}{|c|}{ Aspergillus clavatus } \\
\hline & & \multicolumn{2}{|c|}{ Methanol seed extract Hexane seed extract } & Methanol seed & ne seed extract \\
\hline Griseofulvin & 25 & \multicolumn{2}{|c|}{$46(100)$} & \multicolumn{2}{|c|}{$45(100)$} \\
\hline GC-1 & 25 & $26(57)$ & $21(46)$ & $21(47)$ & $21(47)$ \\
\hline GC-4 & 25 & $28(61)$ & $18(39)$ & $17(38)$ & $24(53)$ \\
\hline $\mathrm{RZ}-19$ & 25 & $19(41)$ & $23(50)$ & $17(38)$ & $23(51)$ \\
\hline RZ-209 & 25 & $18(39)$ & $21(46)$ & $15(30)$ & $21(47)$ \\
\hline RZ-341 & 25 & $19(41)$ & $22(48)$ & $19(42)$ & $22(49)$ \\
\hline
\end{tabular}

Value in parenthesis is percent inhibition of zone 
at par with control $(3.5 \mathrm{ml}$ after $4 \mathrm{~h})$. Carrageen-treated rats of group IV to XIII were given $400 \mathrm{mg} / \mathrm{kg}$ of either methanol or hexane seed extracts. Results indicated that cumin seed extract irrespective of solvent and genotype showed excellent antiinflammatory property at par with diclofenac. Effect of methanol seed extract of cumin genotype $\mathrm{GC}-1$ at $400 \mathrm{mg} / \mathrm{kg}$ was at par with diclofenac in reducing the oedema volume up to $3.5 \mathrm{ml}$ after $4 \mathrm{~h}$ whereas hexane extract reduced oedema volume up to $3.6 \mathrm{ml}$. Similar results were obtained with genotype GC-4. However, hexane seed extract from genotypes RZ-19, RZ-209 and RZ-341 were slightly more effective as compared to methanol seed extract (Table 3). Genotype GC-1 was more effective followed by GC-4, RZ-341, RZ-209 and RZ-19.

In a similar study aqueous and ethanol cumin seed extracts were tested against pain and inflammation and found significant antiinflammatory activity as compared to the control group rats ${ }^{[35]}$. An earlier report also showed that cumin essential oil produced dosedependent antiinflammatory activity in same model and the activity was comparable to that of diclofenac sodium $^{[36]}$. Similarly, methanol extract of cumin inhibited lipoxygenase activity and cuminaldehyde as a 15-LOX inhibitor ${ }^{[37]}$. Cumin genotypes under study possessed good amount of essential oil, which ranged from 2.76 in RZ-341 to 3.64 in GC-4. The essential oil profiles of 5 prominent cumin genotypes were compared and the profiles showed presence of terpenic hydrocarbons, alcohols, aldehydes, ether and esters as major constituents ${ }^{[38]}$. Study revealed significant genotypic variation in cuminaldehyde content from 23.86 to 57.16 . However, results from present study revealed that antiinflammatory effect is a result of combined effect of various constituents rather than cuminaldehyde alone because the genotypes with less cuminaldehyde and considerable amount of terpenic hydrocarbon showed more effect than other genotypes $^{[38]}$.

All the 4 parameters affecting hypolipidemic properties were found to be influenced by both seed extracts of cumin genotypes as presented in Table 4. Total cholesterol was reduced up to 82.7 and 83.2 by methanol and hexane extract of RZ-341, respectively

TABLE 3: EFFECT OF CUMIN SEED EXTRACTS AND DICLOFENAC ON CARRAGEENAN-INDUCED PAW EDEMA IN RATS

\begin{tabular}{|c|c|c|c|c|c|c|}
\hline \multirow{3}{*}{ Treatments/Groups } & \multirow{3}{*}{$\begin{array}{c}\text { Dose } \\
\text { (mg/kg) }\end{array}$} & \multicolumn{5}{|c|}{ Volume of paw edema $(\mathrm{ml})$} \\
\hline & & \multirow{2}{*}{$\mathrm{OH}$} & \multicolumn{2}{|c|}{$2 \mathrm{~h}$} & \multicolumn{2}{|c|}{$4 \mathrm{~h}$} \\
\hline & & & Methanol extract & Hexane extract & Methanol extract & Hexane extract \\
\hline Control (I) & $1 \mathrm{ml}$ & $3.4 \pm 0.33$ & $3.4 \pm 0.54$ & $3.4 \pm 0.54$ & $3.4 \pm 0.021$ & $3.4 \pm 0.021$ \\
\hline Carrageenan (II) & $1 \%$ & $3.3 \pm 0.33$ & $6.2 \pm 0.67^{+++}$ & $6.2 \pm 0.67^{+++}$ & $6.8 \pm 0.31^{+++}$ & $6.8 \pm 0.31^{+++}$ \\
\hline Diclofenac (III) & 12.5 & $3.3 \pm 0.33$ & $5.2 \pm 0.63$ & $5.2 \pm 0.63$ & $3.5 \pm 0.58^{* * *}$ & $3.5 \pm 0.58^{* * *}$ \\
\hline GC-1 (IV and IX) & 400 & $3.2 \pm 0.56$ & $5.0 \pm 0.56$ & $5.4 \pm 0.56$ & $3.5 \pm 0.12^{* * *}$ & $3.6 \pm 0.76^{* * *}$ \\
\hline GC-4 (V and X) & 400 & $3.3 \pm 0.82$ & $5.1 \pm 0.33$ & $5.3 \pm 0.68$ & $3.7 \pm 0.56^{* * *}$ & $3.7 \pm 0.38^{* * *}$ \\
\hline RZ-19 (VI and XI) & 400 & $3.5 \pm 0.37$ & $5.8 \pm 0.47$ & $5.9 \pm 0.84$ & $3.9 \pm 0.55^{* * *}$ & $3.8 \pm 0.66^{* * *}$ \\
\hline RZ-209 (VII and XII) & 400 & $3.5 \pm 0.91$ & $5.8 \pm 0.91$ & $5.7 \pm 0.53$ & $4.1 \pm 0.73$ & $3.6 \pm 0.82^{* * *}$ \\
\hline RZ-341 (VIII and XIII) & 400 & $3.4 \pm 0.62$ & $5.6 \pm 0.93$ & $5.5 \pm 0.43$ & $3.8 \pm 0.58^{* * *}$ & $3.6 \pm 0.56^{* * *}$ \\
\hline
\end{tabular}

All values were represented as mean \pm SEM $(n=6)$; $P$ value: $+++<0.001$; when compared with control animals. $P$ value ${ }^{* * *}<0.001 ;$ when compared with carrageenan treated model. NS= not significant. Groups I to VIII, Methanol seed extract, IX to XIII, Hexane seed extract

TABLE 4: HYPOLIPIDEMIC ACTIVITY OF SEED EXTRACTS OF CUMIN GENOTYPES

\begin{tabular}{|c|c|c|c|c|c|c|c|c|c|}
\hline \multirow[b]{2}{*}{ Treatment } & \multirow[b]{2}{*}{$\begin{array}{c}\text { Dose } \\
(\mathrm{mg} / \mathrm{kg})\end{array}$} & \multicolumn{2}{|c|}{ Total cholesterol } & \multicolumn{2}{|c|}{ Triglycerides } & \multicolumn{2}{|c|}{ LDL } & \multicolumn{2}{|c|}{ HDL } \\
\hline & & $\begin{array}{c}\text { Methanol } \\
\text { seed } \\
\text { extract }\end{array}$ & $\begin{array}{c}\text { Hexane } \\
\text { seed } \\
\text { extract }\end{array}$ & $\begin{array}{c}\text { Methanol } \\
\text { seed } \\
\text { extract }\end{array}$ & $\begin{array}{c}\text { Hexane } \\
\text { seed } \\
\text { extract }\end{array}$ & $\begin{array}{l}\text { Methanol } \\
\text { seed } \\
\text { extract }\end{array}$ & $\begin{array}{l}\text { Hexane } \\
\text { seed } \\
\text { extract }\end{array}$ & $\begin{array}{l}\text { Methanol } \\
\text { seed } \\
\text { extract }\end{array}$ & $\begin{array}{c}\text { Hexane } \\
\text { seed } \\
\text { extract }\end{array}$ \\
\hline Vehicle & $1 \mathrm{ml}$ & \multicolumn{2}{|c|}{$66.7 \pm 6.57$} & \multicolumn{2}{|c|}{$94.8 \pm 8.39$} & \multicolumn{2}{|c|}{$46.6 \pm 4.72$} & \multicolumn{2}{|c|}{$38.2 \pm 5.32$} \\
\hline Only diet & 1000 mg/day & \multicolumn{2}{|c|}{$91.6 \pm 4.91$} & \multicolumn{2}{|c|}{$146.6 \pm 5.27$} & \multicolumn{2}{|c|}{$96.5 \pm 3.19$} & \multicolumn{2}{|c|}{$27.2 \pm 5.48$} \\
\hline Simvastatin & 100 & \multicolumn{2}{|c|}{$77.2 \pm 8.38$} & \multicolumn{2}{|c|}{$109.1 \pm 5.69$} & \multicolumn{2}{|c|}{$48.2 \pm 6.09$} & \multicolumn{2}{|c|}{$35.8 \pm 3.74$} \\
\hline GC-1 & 400 & $87.2 \pm 6.51$ & $88.9 \pm 5.36$ & $127.6 \pm 4.96$ & $134.1 \pm 5.76$ & $65.4 \pm 4.86$ & $71.4 \pm 6.94$ & $32.1 \pm 3.11$ & $30.7 \pm 2.0$ \\
\hline GC-4 & 400 & $84.4 \pm 2.07$ & $85.3 \pm 7.62$ & $137.6 \pm 4.92$ & $132.2 \pm 4.77$ & $69.5 \pm 3.99$ & $72.6 \pm 5.83$ & $28.1 \pm 2.94$ & $29.2 \pm 3.6$ \\
\hline RZ-19 & 400 & $89.6 \pm 4.33$ & $87.3 \pm 2.08$ & $135.2 \pm 3.73$ & $135.6 \pm 4.24$ & $65.4 \pm 5.87$ & $64.2 \pm 4.83$ & $30.0 \pm 2.08$ & $31.2 \pm 3.9$ \\
\hline RZ-209 & 400 & $86.5 \pm 4.81$ & $83.8 \pm 3.84$ & $119.5 \pm 4.95$ & $120.2 \pm 3.57$ & $71.4 \pm 3.91$ & $70.5 \pm 4.86$ & $30.2 \pm 3.94$ & $28.2 \pm 4.4$ \\
\hline $\mathrm{RZ}-341$ & 400 & $82.7 \pm 4.92$ & $83.2 \pm 4.72$ & $126.4 \pm 2.06$ & $127.4 \pm 3.96$ & $67.2 \pm 4.01$ & $66.4 \pm 5.96$ & $31.3 \pm 2.63$ & $30.2 \pm 2.6$ \\
\hline
\end{tabular}

All values are represented as mean \pm SEM $(n=6)$ 
which is similar to that produced by simvastatin (77.3). Level of triglycerides was also lowered in animals treated with either of seed extracts. Methanol and hexane seed extracts of RZ-209 were able to reduce the triglycerides up to 119.5 and 120.1 , respectively from 146.6 in animals fed with high cholesterol diet. The level of triglycerides in animals fed with simvastatin was 109.1. Similarly, LDL level also reduced by methanol seed extract of different cumin genotypes in the range of 65.4-71.4 as against 96.5 in high cholesterol-fed animals and 48.2 in treated animals. Hexane seed extract was also equally effective in reducing LDL levels. Both the extract were able to increase the HDL of which methanol extract of GC-1 was most effective (32.1) followed by seed extract of RZ-341 (31.33) and hexane extract of RZ-19 (31.1). A study indicated that methanol cumin seed extract was more effective as compared to standard drug against increased cholesterol levels due to ovariectomy ${ }^{[39]}$. Consumption of cumin seed powder significantly affects lipid profile and body composition favourably ${ }^{[40]}$. In a study cumin seed extract was found to decrease significantly the level of oxLDL, increased activity of paraoxonase and arylesterase, important enzymes for protection of plasma lipoproteins from oxidative modification ${ }^{[41]}$. A significant decrease in serum triglycerides, cholesterol, LDL-C and increase in serum HDL-C was reported when ethanol cumin seed extract was fed with high fat diet to male Syrian golden hamster ${ }^{[14]}$. Fatty acid methyl ester analysis of cumin seed oil revealed maximum occurrence of monounsaturated fatty acids, oleic acid found in the range of $45.29 \%$ in RZ-19 to $84.81 \%$ in genotype GC-4 along with linoleic acid (10-20\%). Palmitic, palmitoleic and stearic acid are other fatty acids. As compared to other common spices like ginger, chilli and pepper, cumin seeds contains high MUFA content, thus may be recommended for human $\operatorname{diet}^{[20]}$.

Cumin seed extracts irrespective of genotypes were found effective in reducing blood glucose level in diabetic rats (Table 5). Methanol seed extract of cumin genotypes at $400 \mathrm{mg} / \mathrm{kg}$ were able to reduce blood glucose level as RZ-209 (61.91 \%)>GC-4 $(61.64 \%)>$ GC-1 (60.99 \%)>RZ-19 (60.91\%)>RZ$341(60.44 \%)$. The hexane seed extract of genotype GC-4 showed maximum reduction in glucose level $(63.07 \%)$ from 140.18 at $120 \mathrm{~min}$ to 118.13 at 240 min while genotype RZ-19 showed minimum reduction in blood glucose 137.82 to 124.31 at $240 \mathrm{~min}$ $(58.80 \%)$. In all the tested genotypes, maximum activity was recorded in methanol seed extract of RZ209 and hexane seed extract of GC-4.

In the last two decades many studies have been conducted to find effective natural compounds which can substitute synthetic drugs for diabetic patients. The traditional medicinally important natural sources included the spices, which are commonly used folklore remedies for many ailments. Use of cumin seeds in whole or powdered form as well as its extracts has been reported and found effective in reducing blood glucose levels ${ }^{[15]}$. It was also found that oral administration of

TABLE 5: ANTIDIABETIC ACTIVITY OF METHANOLAND HEXANE EXTRACT OF CUMIN ON ORAL GLUCOSE TOLERANCE TEST

\begin{tabular}{|c|c|c|c|c|c|c|c|c|c|c|c|}
\hline \multirow[b]{2}{*}{ Treatment } & \multirow[b]{2}{*}{$\begin{array}{l}\text { Dose } \\
\mathrm{mg} / \mathrm{kg}\end{array}$} & \multicolumn{2}{|c|}{ Zero min } & \multicolumn{2}{|c|}{$30 \mathrm{~min}$} & \multicolumn{2}{|c|}{$60 \mathrm{~min}$} & \multicolumn{2}{|c|}{$120 \mathrm{~min}$} & \multicolumn{2}{|c|}{$240 \mathrm{~min}$} \\
\hline & & $\begin{array}{l}\text { Methanol } \\
\text { seed } \\
\text { extract }\end{array}$ & $\begin{array}{l}\text { Hexane } \\
\text { seed } \\
\text { extract }\end{array}$ & $\begin{array}{l}\text { Methanol } \\
\text { seed } \\
\text { extract }\end{array}$ & $\begin{array}{l}\text { Hexane } \\
\text { seed } \\
\text { extract }\end{array}$ & $\begin{array}{c}\text { Methanol } \\
\text { seed } \\
\text { extract }\end{array}$ & $\begin{array}{l}\text { Hexane } \\
\text { seed } \\
\text { extract }\end{array}$ & $\begin{array}{c}\text { Methanol } \\
\text { seed } \\
\text { extract }\end{array}$ & $\begin{array}{l}\text { Hexane } \\
\text { seed } \\
\text { extract }\end{array}$ & $\begin{array}{c}\text { Methanol } \\
\text { seed } \\
\text { extract }\end{array}$ & $\begin{array}{c}\text { Hexane } \\
\text { seed } \\
\text { extract }\end{array}$ \\
\hline Vehicle only & $1 \mathrm{ml}$ & \multicolumn{2}{|c|}{$\begin{array}{c}91.8 \\
\pm 0.44\end{array}$} & \multicolumn{2}{|c|}{$\begin{array}{c}92.5 \\
\pm 0.53\end{array}$} & \multicolumn{2}{|c|}{$\begin{array}{c}92.0 \\
\pm 0.55\end{array}$} & \multicolumn{2}{|c|}{$\begin{array}{l}90.5 \\
\pm 0.4\end{array}$} & \multicolumn{2}{|c|}{$\begin{array}{c}91.3 \\
\pm 0.56\end{array}$} \\
\hline Glucose & $\begin{array}{c}2000 \\
\mathrm{mg} / \text { day }\end{array}$ & \multicolumn{2}{|c|}{$\begin{array}{r}91.9 \\
\pm 0.89\end{array}$} & \multicolumn{2}{|c|}{$\begin{array}{l}155.6 \\
\pm 0.7\end{array}$} & \multicolumn{2}{|c|}{$\begin{array}{c}181 \\
\pm 0.69\end{array}$} & \multicolumn{2}{|c|}{$\begin{array}{c}153.2 \\
\pm .07\end{array}$} & \multicolumn{2}{|c|}{$\begin{array}{l}145 \\
\pm 0.85\end{array}$} \\
\hline Glibenclamide & 10 & \multicolumn{2}{|c|}{$\begin{array}{c}93.3 \\
\pm 1.00\end{array}$} & \multicolumn{2}{|c|}{$\begin{array}{l}132.5 \\
\pm 0.5\end{array}$} & \multicolumn{2}{|c|}{$\begin{array}{c}141 \\
\pm 0.66\end{array}$} & \multicolumn{2}{|c|}{$\begin{array}{l}124.5 \\
\pm 0.2\end{array}$} & \multicolumn{2}{|c|}{$\begin{array}{c}107 \\
\pm 0.75\end{array}$} \\
\hline GC-1 & 400 & $\begin{array}{l}92.6 \\
\pm 0.4\end{array}$ & $\begin{array}{c}93.5 \\
\pm 0.93\end{array}$ & $\begin{array}{l}137 \\
\pm 2.01\end{array}$ & $\begin{array}{c}136.3 \\
\pm 1.7\end{array}$ & $\begin{array}{c}146 \\
\pm 0.49\end{array}$ & $\begin{array}{c}148 \text {. } \\
\pm 1.95\end{array}$ & $\begin{array}{l}136.2 \\
\pm 1.0\end{array}$ & $\begin{array}{c}132.5 \\
\pm 1.2\end{array}$ & $\begin{array}{c}121 \\
\pm 1.05\end{array}$ & $\begin{array}{c}119 . \\
\pm 1.48\end{array}$ \\
\hline GC-4 & 400 & $\begin{array}{c}92.5 \\
\pm 1.08\end{array}$ & $\begin{array}{l}92.9 \\
\pm 2.94\end{array}$ & $\begin{array}{l}138.7 \\
\pm 1.9\end{array}$ & $\begin{array}{l}142.2 \\
\pm 1.6\end{array}$ & $\begin{array}{l}155 \\
\pm 2.83\end{array}$ & $\begin{array}{c}153 \\
\pm 1.63\end{array}$ & $\begin{array}{l}141.9 \\
\pm 1.2\end{array}$ & $\begin{array}{c}140.2 \\
\pm 1.4\end{array}$ & $\begin{array}{l}120 \\
\pm 0.36\end{array}$ & $\begin{array}{c}118 \\
\pm 1.86\end{array}$ \\
\hline $\mathrm{RZ}-19$ & 400 & $\begin{array}{r}93.2 \\
\pm 2.39\end{array}$ & $\begin{array}{r}92.8 \\
\pm 1.82\end{array}$ & $\begin{array}{l}145.7 \\
\pm 2.9\end{array}$ & $\begin{array}{l}146.2 \\
\pm 2.0\end{array}$ & $\begin{array}{c}157 \\
\pm 1.95\end{array}$ & $\begin{array}{c}154 \\
\pm 2.43\end{array}$ & $\begin{array}{l}139.5 \\
\pm 2.6\end{array}$ & $\begin{array}{l}137.8 \\
\pm 1.6\end{array}$ & $\begin{array}{c}121 \\
\pm 1.73\end{array}$ & $\begin{array}{c}124 \\
\pm 1.34\end{array}$ \\
\hline RZ-209 & 400 & $\begin{array}{r}92.7 \\
\pm 1.59\end{array}$ & $\begin{array}{r}93.2 \\
\pm 1.51\end{array}$ & $\begin{array}{l}147.4 \\
\pm 2.3\end{array}$ & $\begin{array}{l}146.1 \\
\pm 1.8\end{array}$ & $\begin{array}{c}151 \\
\pm 1.27\end{array}$ & $\begin{array}{c}150 \\
\pm 1.89\end{array}$ & $\begin{array}{l}135.2 \\
\pm 1.7\end{array}$ & $\begin{array}{l}134.1 \\
\pm 2.0\end{array}$ & $\begin{array}{c}120 \\
\pm 1.37\end{array}$ & $\begin{array}{c}120 \\
\pm 2.94\end{array}$ \\
\hline$R Z-341$ & 400 & $\begin{array}{r}92.9 \\
\pm 1.93\end{array}$ & $\begin{array}{c}93.2 \\
\pm 1.48\end{array}$ & $\begin{array}{c}145.1 \\
\pm 1.9\end{array}$ & $\begin{array}{c}146.2 \\
\pm 1.4\end{array}$ & $\begin{array}{c}151 \\
\pm 2.67\end{array}$ & $\begin{array}{c}152 \\
\pm 2.03\end{array}$ & $\begin{array}{c}133.1 \\
\pm 1.0\end{array}$ & $\begin{array}{c}132.7 \\
\pm 1.8\end{array}$ & $\begin{array}{c}122 \\
\pm 1.58 \\
\end{array}$ & $\begin{array}{c}121 \\
\pm 1.94 \\
\end{array}$ \\
\hline
\end{tabular}

All values are represented as mean \pm SEM $(n=6)$ 
TABLE 6: ANTIHYPERTENSIVE ACTIVITY OF METHANOL AND HEXANE EXTRACT OF CUMIN

\begin{tabular}{lcccccc}
\hline \multirow{2}{*}{ Group } & \multirow{2}{*}{ Treatment } & \multicolumn{4}{c}{ MABP at different time interval (mm Hg) } \\
\cline { 3 - 6 } & & MABP after removing clip & $\mathbf{5}$ min & $\mathbf{1 5}$ min & $\mathbf{3 0}$ min & $\mathbf{6 0}$ min \\
\hline I & Control & 84 & 84 & 85 & 85 & 86 \\
II & Captopril & 122 & 47 & 47 & 39 & 34 \\
III & GC-1 (M) & 127 & 91 & 93 & 68 & 65 \\
IV & GC-1 (H) & 126 & 86 & 87 & 85 & 73 \\
\hline
\end{tabular}

MABP is mean arterial blood pressure

cumin for $6 \mathrm{w}$ to diabetic rats was more effective than glibenclamide ${ }^{[15]}$. Other studies conducted on rabbits showed that oral administration of cumin significantly increased glucose tolerance ${ }^{[14,42,43]}$. The compound responsible for antidiabetic effect of cumin seeds is cuminaldehyde ${ }^{[4]}$. In the present study too, methanol seed extract of genotypes RZ-209, which has maximum cuminaldehyde content was found most effective in lowering blood glucose level ${ }^{[38]}$.

Cumin seed extracts of genotype GC-1 were able to reduce mean arterial blood pressure (MABP). Methanol extract was more effective than hexane extract. MABP was recorded 65 and $73 \mathrm{~mm}$ of $\mathrm{Hg}$ after $1 \mathrm{~h}$ in treatment of methanol and hexane extract, respectively as compared to $34 \mathrm{~mm}$ in captopril-treated rats and $86 \mathrm{~mm}$ in controlled animals. After $30 \mathrm{~min}$ of treatment administration of both the extracts, MABP recorded at par with control (Table 6). Aqueous cumin seed extract has also been evaluated for its antihypertensive potential on animal model ${ }^{[18]}$. Results indicated antihypertensive effect of aqueous cumin seed extract and its role in arterial endothelial nitric oxide synthase expression and decreased systolic blood pressure in hypertensive rats. This study also suggest augmentation function of cumin seeds in ameliorate inflammatory and oxidative stress in hypertensive rats.

Present study indicated that hexane seed extract of cumin genotype RZ-209 and RZ-341 possessed more antibacterial properties while methanol extract of RZ341 showed slightly more hypolipidemic properties. Similarly hexane extract of genotypes GC-1 and GC-4 exhibited more antihypertensive and antifungal activity, respectively. Antiinflammation activity was more in methanol extract of genotype GC-1 and antidiabetic activity was more in hexane extract of genotype GC-1. This genotypic variation may be due to distinct morphology as well as different chemical constitution of two genotypes as well as agro-ecological and edaphic interventions. Genotype prefix with RZ are cumin varieties developed from state Rajasthan, India while, genotypes prefix with GC are variety from state Gujarat, India showed significantly different phenotype. $\mathrm{RZ}$ varieties are having less leaf biomass and more height while $\mathrm{GC}$ varieties are comparatively having more leaf biomass with bushy appearance. More cuminaldehyde content has been reported in genotype RZ- 209 as compared to GC-4 whereas monoterpene and cymene was higher in GC-4 ${ }^{[1,38]}$.

Besides flavour and pungent taste cumin seeds are also rich nutritionally. Proximate analysis of cumin seeds indicated presence of proteins with dietary fiber. Cumin seeds contains good amount of minerals especially iron $^{[45]}$ while cuminaldehyde, cuminic alcohol, cymene and terpenoids are the major volatile components of cumin seed essential oil ${ }^{[1,46,47]}$. Though, cumin seeds are being used in Asian and Indian cuisines mostly for culinary purposes and in meagre quantity as compared to other commodities belonging to this category, specially onion, garlic, chilli and coriander. Intake of cumin may be enhanced in the form of some value added cumin products like cumin syrup, salad dressings, as an appetizer or as decoctions and or extracts mentioned above under supervision to realise its medicinal and pharmacological properties. These decoctions and extracts can be produced on industrial scale to promote its health beneficial attributes. Thus, cumin seeds in various forms can be used as a source of medicinally important compounds for their use in developing functional foods also.

\section{Acknowledgements:}

Authors duly acknowledge the facilities provided by the Indian Council of Agricultural Research (ICAR), Govt. of India.

\section{REFERENCES}

1. Sharma LK, Agarwal D, Rathore SS, Saxena SN. Effect of cryogenic grinding on volatile and fatty oil constituents of cumin (Cuminum cyminum L.) genotypes. J Food Sci Technol 2016;(53):2827-34.

2. Srinivasan K. Cumin (Cuminum cyminum) and black cumin (Nigella sativa) seeds: Traditional uses, chemical constituents, and nutraceutical effects. J Food Saf Food Qual 2018;2:1-16.

3. Rathore SS, Saxena SN, Singh B. Potential health benefits of major seed spices. Int J Seed Spices 2013;3(2):1-12. 
4. Al-Snafi AE. The pharmacological activities of Cuminum cyminum- A review. IOSR J Pharmi 2016;6:46-65.

5. Dua A, Gupta SK, Mittal A, Mahajan R. A Study of Antioxidant properties and antioxidant compounds of cumin (Cuminum cyminum). Int J Pharm Biol Arch 2012;3(5):1110-16.

6. Atrooz OM. The Effects of Cuminum cyminum L. and Carum carvi L. seed extracts on human erythrocyte hemolysis. Int J Biol Sci 2013;592:57-63.

7. Al Juhaimi FY, Ghafoor K. Extraction optimization and in vitro antioxidant properties of phenolic compounds from Cumin (Cuminum cyminum L.) seed. Int Food Res J 2013;20:166975.

8. Bettaieb I, Bourgou S, Wannes WA, Hamrouni I, Limam F, Marzouk B. Essential oils, phenolics, and antioxidant activities of different parts of cumin (Cuminum cyminum L.). J Agric Food Chem 2010.58:10410-18.

9. Thippeswamy NB, Akhilender NK. Antioxidant potency of cumin varieties cumin, black cumin and bitter cumin on antioxidant systems. Eur Food Res Tech 2005;220:472-76.

10. El-Said AHM, El-Hady G. Antifungal activities of Cuminum cyminum and Pimpinella anisum essential oils. Int J Curr Micro Appl Sci 2014;3:937-44.

11. Dua A, Garg G, Singh B, Mahajan R. Antimicrobial properties of methanolic extract of cumin (Cuminum Cyminum) seed. Int J Res Ayu Pharm 2013;4:104-7.

12. Patil S, Maknikar P, Wankhade S, Ukesh C, Rai M. Antifungal effect of cumin essential oil alone and in combination with antifungal drugs. Nusantara Biosci 2015;7:55-9.

13. Farag MA, Ali SE, Hodaya RH, El-Seedi HR, Sultani HN, Laub A, et al. Phytochemical Profiles and Antimicrobial Activities of Allium cepa Red cv. and A. sativum Subjected to Different Drying Methods: A Comparative MS-Based Metabolomics. Molecules 2017;22:761.

14. Srivsatava R, Srivastava SP, Jaiswal N, Mishra A, Maurya R, Srivastava AK. Anti-diabetic and anti-dyslipidemic activities of Cuminum cyminum L. in validated animal models. Medicinal Chem Res 2010;20:1656.

15. Willatgamuwa SA, Platell K, Saraswathi G, Srinivasan K. Anti-diabetic influence of dietary cumin seeds (Cuminum cyminum) in streptozotocin induced diabetic rats. Nutr Res 1998;18:131-42.

16. Dandapani S, Subramanian VR, Rajagopal S, Namasivayam $\mathrm{N}$. Hypolipidemic effect of Cuminum cyminum L. on alloxaninduced diabetic rats. Pharm Res 2002;46:251-5.

17. Andallu B, Ramya V. Anti-hyperglycemic, cholesterollowering and HDL-raising effects of cumin (Cuminum cyminum) seeds in Type - 2 Diabetes. J Nat Remedies 2007;7:142-9.

18. Kalaivani P, Saranya RB, Ramakrishnan G, Ranju V, Sathiya $\mathrm{S}$, Gayathri V, et al. Cuminum cyminum, a dietary spice, attenuates hypertension via endothelial nitric oxide synthase and NO pathway in renovascular hypertensive rats. Clin Exp Hypertens 2013;35:534-42.

19. Mnif S, Aifa S. Cumin (Cuminum cyminum L.) from traditional uses to potential biomedical applications. Chem Biodivers 2015; 12:733-42.

20. Sowbhagya HB. Chemistry, technology, and nutraceutical functions of cumin (Cuminum cyminum L): An Overview. Crit Rev Food Sci Nutr 2013;53:1-10.

21. Dubey PN, Saxena SN, Mishra BK, Kant K, Lal G, Sharma LK, et al. Essential oil constituents and unsaturated fatty acids in Indian Cuminum cyminum L. seed oil under varying agro climatic environments. Int J Seed Spices 2018;8:7-14.

22. Agrawal D, Sharma LK, Rathore SS, Zachariah TZ, Saxena SN. Analysis of total phenolics and antioxidant activity in seed and leaf extracts of cumin genotypes. Int J Seed Spices 2016;6(1):43-9.

23. Mueller JH, Hinton J. A protein-free medium for primary isolation of the Gonococcus and Meningococcus. Proceeding Society Exp Biol Med 1941;48:330.

24. Panse VG, Sukhatme PV. Statistical Methods for Agricultural Workers. New Delhi: Indian Council of Agricultural Research; 1967.

25. Chaudhary N, Husain SS, Ali M. Chemical composition and antimicrobial activity of cumin oil (Cuminum cyminum, L.). J Pharm Pharm Sci 2014;3:1428-41.

26. Wanner J, Bail S, Jirovetz L, Buchbauer G, Schmidt E, Gochev $\mathrm{V}$, et al. Chemical composition and antimicrobial activity of cumin oil (Cuminum cyminum, Apiaceae). Nat Prod Commun 2010;5:1355-8.

27. Bameri Z, Amini-Boroujeni N, Saeidi S, Bazi S. Antimicrobial activity of Cuminum yminum against biofilm E. coli. Int Res J Appl Basic Sci 2013;5:1232-4.

28. Jirovetz L, Buchbauer G, Stoyanova AS, Georgiev, EV, Stanka T, Damianova, ST. Composition, quality control and antimicrobial activity of the essential oil of cumin (Cuminum cyminum L.) seeds from Bulgaria that had been stored for up to 36 years. Int J Food Sci Technol 2005;40:305-10.

29. Fakoor MH, Rasooli I. Pathogen control by antioxidative characteristics of Cuminum cyminum and Rosmarinus officinalis essential oils. Int Soc Horti Sci 2008;786:125-36.

30. Hu L, Chen C, Yi X, Feng J, Zhang X. Inhibition of p-isopropyl benzaldehyde and p-isopropyl benzoic acid extracted from Cuminum cyminum against plant pathogens. Acta Bot Boreali Occident Sinica 2008;28:2349-54.

31. Romagnol C, Andreotti E, Maietti S, Rai M, Mares D. Antifungal activity of essential oil from fruits of Indian Cuminum cyminum. Pharm Biol 2010;48:834-38.

32. Tavakoli HR, Mashak Z, Moradi B, Sodagari HR. Antimicrobial activities of the combined use of Cuminum cyminum L. essential oil, and storage temperature against Salmonella typhimurium and Staphylococcus aureus in vitro. Jundishapur J Microbiol 2015;8:238-48.

33. Allahghadri T, Rasooli I, Owlia P, Nadooshan MJ, Ghazanfari $\mathrm{T}$, Taghizadeh $\mathrm{M}$, et al. Antimicrobial property, antioxidant capacity, and cytotoxicity of essential oil from cumin produced in Iran. J Food Sci 2010;75:H54-H61.

34. Iacobellis NS, Cantore PL, Capasso F, Senatore F. Antibacterial activity of Cuminum cyminum L. and Carum carvi L. essential oils. J Agric Food Chem 2005;53:57-61.

35. Bhat SP, Rizvi W, Kumar A. Effect of Cuminum cyminum L. seed extracts on pain and inflammation. J Nat Remedies 2014;14:186-92.

36. Shivakumar SI, Shahapurkar AA, Kalmath KV, Shivakumar B. Anti-inflammatory activity of fruits of Cuminum cyminum L. Der Pharm Lett 2010;2:22-4.

37. Tomy MJ, Dileep KV, Prasanth S, Preethidan DS, Sabu A, Sadasivan $\mathrm{C}$, et al. Cuminaldehyde as a lipoxygenase inhibitor: in vitro and in silico validation. Appl Biochem Biotechnol 2014; 174:388-97.

38. Agarwal D. Study on genotypic variation in chemical profiling and medicinal properties of seed spices crops [dissertation]. Udaipur, Rajasthan India: Pacific University; 2017. 
39. Shirke SS, Jagtap AJ. Effects of methanolic extract of Cuminum cyminumon total serum cholesterol in ovariectomized rats. Ind J Pharm 2009;41:91-3.

40. Zare R, Heshmati F, Fallahzadeh H, Nadjarzadeh A. Effect of cumin powder on body composition and lipid profile in overweight and obese women. Complementary Therapies in Clin Pract 2014;20:297-301.

41. Samani KG, Farrokhi E. Effects of cumin extract on oxLDL, paraoxanase- 1 activity, FBS, total cholesterol, triglycerides, HDL-C, LDL-C, Apo A1, and Apo B in the patients with hypercholesterolemia. Int J Health Sci 2014;8:39-43.

42. Srinivasan K. Plant foods in the management of diabetes mellitus: Spices as beneficial antidiabetic food adjuncts. Int J Food Sci Nutri 2005;56:399-414.

43. Kumar P, Reddy PY, Srinivas PN, Reddy GB. Delay of diabetic cataract in rats by the anti-glycating potential of cumin through modulation of $\alpha$-crystallin chaperone activity. J Nutr Biochem 2009;20:553-62.

44. Lee HS. Cuminaldehyde: aldose reductase and alphaglucosidase inhibitor derived from Cuminum cyminum L. seeds. J Agric Food Chem 2005;53:2446-50.

45. Dubey PN, Saxena SN, Mishra BK, Aishwath OP, Solanki RK, Singh B, et al. Assessment of variability in physical and chemical composition of Cuminum cyminum seeds from arid and semiarid India. Indian J Agric Sci 2016;86:1366-70.

46. Dubey PN, Saxena SN, Mishra BK, Solanki RK, Vishal MK, Singh B, et al. Preponderance of cumin (Cuminum cyminum L.) essential oil constituents across cumin growing AgroEcological Sub Regions, India. Ind Crops Prod 2017;95:50-9.

47. Bettaieb I, Bourgou S, Sriti J, Msaada K, Limam F, Marzouk B. Essential oils and fatty acids composition of Tunisian and Indian cumin (Cuminum cyminum L.) seeds: a comparative study. J Sci Food Agric 2011;91:2100-7. 